\title{
Effect of nitrogen flushing and storage temperature on flavor and shelf-life of whole milk powder
}

\author{
M. A. Lloyd, ${ }^{*}$ S. J. Hess, $†$ and M. A. Drake ${ }^{\star 1}$ \\ ${ }^{*}$ Department of Food, Bioprocessing and Nutritional Sciences, Southeast Dairy Food Research Center, North Carolina State University, \\ Raleigh 27694 \\ †The Hershey Company, Technical Center, Hershey, PA 17033
}

\section{ABSTRACT}

The US industry standard for shelf-life of whole milk powder (WMP) is 6 to $9 \mathrm{mo}$, although previous research has demonstrated flavor changes by 3 mo at ambient storage. This study evaluated the influence of packaging atmosphere, storage temperature, and storage time on WMP shelf-life using sensory and instrumental techniques. Two commercial batches of WMP were repackaged in plastic laminate pouches with air or nitrogen and stored at $2^{\circ} \mathrm{C}$ or $23^{\circ} \mathrm{C}$ for 1 yr. Descriptive analysis was conducted using a 10-member trained panel; volatile analysis was performed using solid-phase microextraction with gas chromatographymass spectrometry. Consumer acceptance $(\mathrm{n}=75)$ was conducted every 3 mo with reconstituted WMP and white and milk chocolate made from each treatment. Data were analyzed using ANOVA with Fisher's LSD, Pearson correlation analysis, and principal component analysis. Air-stored WMP had higher peroxide values, lipid oxidation volatiles, and grassy and painty flavors than nitrogen-flushed WMP. Storage temperature did not affect levels of straight chain lipid oxidation volatiles; $23^{\circ} \mathrm{C}$ storage resulted in higher cooked and milkfat flavors and lower levels of grassy flavor compared with $2{ }^{\circ} \mathrm{C}$ storage. Consumer acceptance was negatively correlated with lipid oxidation volatiles and painty flavor. Nitrogen flushing prevented the development of painty flavor in WMP stored up to $1 \mathrm{yr}$ at either temperature, resulting in chocolate with high consumer acceptance. Nitrogen flushing can be applied to extend the shelf life of WMP for use in chocolate; storage temperature also plays a role, but to a lesser extent.

Key words: whole milk powder, flavor, storage, dried dairy ingredient

\section{INTRODUCTION}

Whole milk powder (WMP) contains 26 to $40 \%$ fat, making it very susceptible to oxidation, which can

Received September 14, 2008.

Accepted January 8, 2009.

${ }^{1}$ Corresponding author: mdrake@unity.ncsu.edu result in off-flavors (USDEC, 2005). The US industry standard for shelf-life of WMP is 6 to 9 mo under storage at $<27^{\circ} \mathrm{C}$ and $<65 \%$ relative humidity (USDEC, 2005), although previous research demonstrated flavor changes by 3 mo in ambient-temperature storage (Carunchia Whetstine and Drake, 2007). Increasing the storage stability of this commodity is of great interest to producers and end users.

Some factors that influence WMP flavor and shelflife include initial milk quality, processing variables, air quality, moisture content, packaging, oxygen exposure, addition of antioxidants, light exposure, and storage temperature (Hall and Lingnert, 1984; Baldwin and Ackland, 1991; van Mil and Jans, 1991; Nielsen et al., 1997; Stapelfeldt et al., 1997). Van Mil and Jans (1991) reported a 3-yr shelf-life for WMP processed and stored under optimal conditions, including: 1) moderate heat treatment of $95^{\circ} \mathrm{C}$ for 2 min [whey protein nitrogen (WPN) of 1.7$] ; 2$ ) moisture content at least $2.8 \% ; 3$ ) storage temperature $\leq 20^{\circ} \mathrm{C}$; and 4) air- and moistureproof oxygen-reduced packaging. Many researchers have found substantial benefits with reduced-oxygen storage for WMP (Tuohy, 1984; van Mil and Jans, 1991; McCluskey et al., 1997). Most WMP storage studies have evaluated WMP at ambient or elevated storage temperatures (van Mil and Jans, 1991; Stapelfeldt et al., 1997), but information is lacking on WMP stored at cooler temperatures. Whole milk powder may be classified as low, medium, or high heat based on undenatured WPN, with values of $\geq 6,1.51$ to 5.99 , and $\leq 1.5 \mathrm{mg}$ undenatured whey protein/g of powder, respectively (USDEC, 2005). Stapelfeldt et al. (1997) found WMP to be most stable when the fluid product was heated under medium $\left(80^{\circ} \mathrm{C} / 20 \mathrm{~s}\right)$ or high $\left(88^{\circ} \mathrm{C} / 20 \mathrm{~s}\right)$ heat treatments before spray drying, with water activities between 0.1 and 0.2 (as opposed to 0.3 ), and stored at $25^{\circ} \mathrm{C}$ (rather than $45^{\circ} \mathrm{C}$ ).

Flavor is the main factor influencing consumer acceptance of WMP (Nursten, 1997; Hough et al., 2002; Drake, 2004). More than $75 \%$ of the WMP manufactured in the Unites States goes into confectionary products such as chocolate, with the remainder used in 
baked goods, dry sauce and soup mixes, dairy beverages, or ice cream (USDEC, 2005). Off-flavors in WMP can carry through into the final product and result in consumer complaints. Caudle et al. (2005) found that off-flavors in skim milk powder (SMP) carried through into yogurt, hot cocoa, and white chocolate, resulting in decreased consumer acceptance. Bolenz et al. (2003) studied milk chocolate made with a variety of dairy ingredients, including WMP, SMP, anhydrous milkfat, and whey protein concentrate, and found that consumer acceptance decreased with the presence of malty or offnotes contributed by stored dairy ingredients. However, research is lacking on consumer acceptance of stored WMP and chocolate made from stored WMP. The objective of this research was to evaluate the influence of WMP packaging atmosphere, storage temperature, and storage time on WMP shelf life, as measured by flavor and stability of WMP and consumer acceptance of WMP and chocolate made with WMP. Both instrumental and sensory tests were conducted to achieve these objectives.

\section{MATERIALS AND METHODS}

Approval for use of human subjects was obtained from the Institutional Review Board at North Carolina State University.

\section{WMP}

Freshly produced ( $<1 \mathrm{mo})$, nonagglomerated WMP $(500 \mathrm{~kg})$ was shipped from a commercial production facility in CA to Hershey, PA, where it was repackaged in pouches made from a 340-gauge nylon-vinyl alcoholpolyethylene laminate with an oxygen transmission rate of $1.5 \mathrm{~mL} / \mathrm{m}^{2}$ per d (Weldon, Oshkosh, WI). Approximately $5.4 \mathrm{~kg}$ of WMP were put into each pouch. Half of the pouches were treated with a vacuum to -0.9 bar and nitrogen to -0.2 bar before sealing. The others were sealed with ambient air and no vacuum. Each treatment was protected from light and stored at $2^{\circ} \mathrm{C}$ or $23^{\circ} \mathrm{C}$ in temperature-controlled rooms at $50 \%$ relative humidity for $1 \mathrm{yr}$ and evaluated every $2 \mathrm{mo}$, unless otherwise specified. The experimental design was replicated twice with a different commercial shipment of WMP. Where indicated, WMP was reconstituted to $10 \%$ SNF before analysis with odor-free deionized water according to the equation in International Dairy Federation Method 99C (IDF, 1997): grams of WMP in $90 \mathrm{~g}$ of water $=1,000 /(100-\%$ fat $)$.

\section{Physicochemical Tests}

Initial Tests. Upon receipt, a subsample of each WMP was sent to an independent lab (Tulare, CA) for duplicate measurements of moisture, undenatured WPN index, fat, and free fat. Moisture content was measured using the vacuum oven method from DA Instruction 918-RL (USDA-AMS, 2001). Whey protein nitrogen and fat (Mojonnier method) were measured as described by Wehr and Frank (2004). Free fat was measured based on the method of Sørensen et al. (1978). Copper and iron were measured in duplicate by the NCSU Analytical Services Laboratory (Raleigh, NC) using a standard dry ash method with inductively coupled plasma optical emission spectroscopy. For this analysis, $2.5 \mathrm{~g}$ of WMP was 1) ashed overnight at $500^{\circ} \mathrm{C}$ in a muffle furnace; 2) cooled; 3 ) mixed with approximately $1.5 \mathrm{~mL}$ of distilled water and $4 \mathrm{~mL}$ of $6 \mathrm{~N} \mathrm{HCl}$ (VWR International, West Chester, PA) and heated to dryness on a steam plate to remove silicates; 4) transferred to a 50-mL volumetric flask with approximately 4 $\mathrm{mL}$ of $6 \mathrm{~N} \mathrm{HCl}$; and 5) brought to volume with distilled water for inductively coupled plasma optical emission spectroscopy analysis (Lentz, 2008). Water activity was measured in duplicate using an Aqualab series $3 \mathrm{TE}$ water activity meter (Decagon Devices, Pullman, WA). Both water activity and moisture were also measured at 2-mo intervals through 12 mo of storage.

Headspace Oxygen. Headspace oxygen of each WMP package was measured before other analyses at each time point (every 2 mo) using a Mocon HS750 headspace analyzer (Mocon Inc., Minneapolis, MN) calibrated to ambient air (20.9\% oxygen). A 1-cm rubber septum with adhesive on one side was attached to the package. Then, $10 \mathrm{~mL}$ of headspace gas was drawn out with a syringe and injected into the analyzer to generate a percentage oxygen reading. If a nitrogenflushed package was above $6.5 \%$ oxygen (indicative of a poor package seal), it was excluded from further study and an additional package was sampled.

Peroxide Value. Peroxide value (PV) was measured in triplicate every 2 mo using the Peroxysafe STD Kit with the Saftest System (MP Biomedicals Inc., Solon, $\mathrm{OH})$.

Color. Every 2 mo, CIE L* (lightness) a* (redness) $\mathrm{b}^{*}$ (yellowness) values were obtained in triplicate with a Minolta CR-300 Chroma Meter using light source "C" (Konica Minolta Sensing Americas, Inc., Ramsey, NJ) and a $60 \times 15 \mathrm{~mm}$ Petri dish (Becton Dickinson Labware, Franklin Lakes, NJ). Both dry and reconstituted powders (10\% SNF) and liquids were filled to the brim ( $\sim 9 \mathrm{~mm}$ depth) of the larger diameter Petri dish top; the dry powder was compressed with the smaller diameter bottom portion of the dish. Samples were measured at approximately $22^{\circ} \mathrm{C}$.

Solubility Index. Every 4 mo, solubility index was determined in duplicate according to the American Dairy Products Institute method (ADPI, 2002). Whole 
milk powder was reconstituted to $10 \%$ SNF using the equation described previously. Solubility index was reported as milliliters of sediment in conical centrifuge tubes (Kimble No. 45167-50, Fisher Scientific, Pittsburgh, PA) after centrifugation at $164 \times g$ for $10 \mathrm{~min}$.

\section{Volatile Analysis}

Volatile compounds of WMP were analyzed in triplicate at $0,2,3,4,6,8,10$, and 12 mo using solid-phase microextraction and a Varian CP-3380 gas chromatograph equipped with a Saturn 2000 ion trap mass selective detector from Varian Inc. (Palo Alto, CA), using a method similar to that reported by Wright et al. (2008). Chromatography was performed using a $30 \mathrm{~m}$ length $\times$ $0.25 \mathrm{~mm}$ i.d. $\times 0.25 \mu \mathrm{m}$ df Rtx- $5 \mathrm{~ms}$ column (Restek, Bellefonte, PA) with helium carrier gas at a flow rate of $1 \mathrm{~mL} / \mathrm{min}$. Oven temperature was ramped from $40^{\circ} \mathrm{C}$ to $250^{\circ} \mathrm{C}$ at a rate of $8^{\circ} \mathrm{C} / \mathrm{min}$ with $5 \mathrm{~min}$ initial and final hold times. Mass selective detector conditions were as follows: $80^{\circ} \mathrm{C}$ manifold, $120^{\circ} \mathrm{C}$ transfer line, $150^{\circ} \mathrm{C}$ ion trap. Chemical standards and alkanes were obtained from Sigma Aldrich (St. Louis, MO); methanol was obtained from VWR International.

Whole milk powder was reconstituted to $10 \% \mathrm{SNF}$ using $90 \mathrm{~mL}$ odor-free deionized water. Five microliters of internal standard $(5 \mu \mathrm{L}$ of E-2-hexenal in $5 \mathrm{~mL}$ of methanol) was added to reconstituted milk to make a final concentration of $45 \mu \mathrm{g} / \mathrm{kg}$ of milk. Twenty grams of the reconstituted sample with the internal standard was added to a $40-\mathrm{mL}$ amber vial with $1.0 \mathrm{~g}$ of sodium chloride (Fisher Scientific), an $8 \times 13 \mathrm{~mm}$ stir bar (VWR International), and a poly(tetrafluoroethyene) coated septum (Supelco, Bellefont, PA). A water blank was made by adding the internal standard to $90 \mathrm{~mL}$ of deodorized water and then adding $20 \mathrm{~g}$ of this solution to a $40-\mathrm{mL}$ vial as described above. An alkane series was prepared by adding $1 \mu \mathrm{L}$ of alkane solution (approximately $40 \mathrm{mg}$ of $\mathrm{C} 7-\mathrm{C} 24 / \mathrm{kg}$ of hexane) into an empty 40-mL vial and sealed as described above and used to calculate retention indices of volatile compounds.

Sample vials were placed in a heating block at $40^{\circ} \mathrm{C}$ for $30 \mathrm{~min}$ to equilibrate. A $2.0 \mathrm{~cm}$ DVB/Carboxen/ PDMS Stableflex fiber (Supelco) was inserted into the heating block and exposed at a depth of $2.0 \mathrm{~cm}$ for an additional $30 \mathrm{~min}$, followed by injection into the gas chromatograph for 5 min at a depth of $3.0 \mathrm{~cm}$. Volatile compounds were identified using the NIST05 mass spectral library (National Institute of Standards and Technology, Gaithersburg, MD), retention indices (van Den Dool and Kratz 1963), and by comparison with authentic standard compounds injected under the same conditions.
Compounds were selected for quantification based on previous literature (Hall and Andersson, 1985; Hall et al., 1985; Vazquez-Landaverde et al., 2005; Carunchia Whetstine and Drake, 2007) and comparison of chromatogram peaks over storage. Multiple-point internal standard curves were generated in odor-free water using the same protocol described above to cover 5 concentration levels in the range found in the samples for each of the following compounds: dimethyl sulfide, 3-methylbutanal, 2-methylbutanal, 2-heptanone, 1-octen-3-ol, 3-octen-2-one, hexanal, heptanal, octanal, and nonanal. Stock solutions were made by dissolving compounds in methanol, with final dilution into $90 \mathrm{~mL}$ of odor-free water with the internal standard. Data were plotted with the response ratio (peak area of standard / peak area of internal standard) on the $y$-axis and concentration ratio (concentration of standard/concentration of internal standard on the $x$-axis. Regression equations were generated based on the best linear fit of the data.

\section{Sensory Analysis}

Whole milk powder was reconstituted to $10 \% \mathrm{SNF}$ with odor-free deionized water and stored at $4 \mathrm{C}$ for descriptive and consumer testing. Samples were evaluated within $12 \mathrm{~h}$ of reconstitution. All samples were served with 3-digit blinding codes. Samples were presented using a Williams design for a balanced order of presentation (MacFie et al., 1989).

Descriptive Analysis. Descriptive analysis profiles for each sample were determined by a 10 -member trained panel ( 7 females, 3 males, ages 22 to $47 \mathrm{yr}$, each with at least $100 \mathrm{~h}$ of prior experience with descriptive analysis of dairy ingredients) using the Spectrum method (Meilgaard et al., 1999) and the dried dairy ingredient lexicon developed by Drake et al. (2003) and previously applied to WMP by Carunchia Whetstine and Drake (2007). The following attributes were rated: overall aroma intensity; cooked, milkfat, sweet aromatic/caramelized, grassy, painty, and cardboard flavors; sweet taste; and astringency. About $25 \mathrm{~mL}$ of reconstituted WMP was poured into 60-mL plastic soufflé cups with lids (Solo Cup Company, Highland Park, IL) and served at $20^{\circ} \mathrm{C}$. Samples were evaluated in duplicate by each panelist initially and after 2, 3, 4, 6, 8, 10 and 12 mo of storage.

Panelists were trained using fresh and aged WMP samples. Evaluations were conducted in individual sensory booths using Compusense 5 version 4.6 software (Compusense, Guelph, Ontario, Canada) for data collection. Panelists received a set of 8 samples to evaluate in each session, with a 30 -min break between sessions. No more than 2 sessions were conducted any given day. 
Table 1. Percentages (wt/wt) of ingredients in milk and white chocolate formulations

\begin{tabular}{lcc}
\hline Ingredient & $\begin{array}{c}\text { Milk } \\
\text { chocolate }\end{array}$ & $\begin{array}{c}\text { White } \\
\text { chocolate }\end{array}$ \\
\hline Sucrose (Domino Specialty Ingredients, Baltimore, MD) & 45.47 & 50.47 \\
Cocoa mass (The Hershey Company, Hershey, PA) & 11 & 0 \\
Whole milk powder & 25 & 25 \\
Deodorized cocoa butter (ADM, Decatur, IL) & 18 & 24 \\
Vanillin (Rhodia Inc., Cranbury, NJ) & 0.03 & 0.03 \\
Lecithin (Degussa Texturant Systems; Atlanta, GA) & 0.4 & 0.4 \\
PGPR $^{1}$ (Danisco USA, New Century, KS) & 0.1 & 0.1 \\
\hline
\end{tabular}

${ }^{1} \mathrm{PGPR}=$ polyglycerol polyricinoleate, an emulsifier.

Deionized water was provided for panelists to refresh their palates between samples. Empty cups were also provided for sample expectoration. Warm-up samples of fresh fluid milk, as well as examples of fresh (free of grassy or painty flavors), grassy and painty flavored reconstituted WMP (previously evaluated and discussed by the panel) were provided at each session for panelist calibration.

Consumer Acceptance. Consumer acceptance was conducted every 3 mo with reconstituted WMP and white and milk chocolate made from each treatment, with each product tested on separate days. A freshly produced WMP or chocolate manufactured with freshly produced WMP was also included as a control. A fresh fluid milk control purchased from a local retail outlet was also included as a control in the reconstituted WMP testing. For consumer testing, self-reported milk or chocolate (depending on product tested) consumers aged 20 to $60 \mathrm{yr}$ were recruited from the university population through e-mail listservs and fliers. Consumers $(\mathrm{n}=75$ per treatment/batch $)$ rated overall acceptance (9-point hedonic scale, $1=$ dislike extremely and $9=$ like extremely). For WMP, approximately 90 $\mathrm{mL}$ of reconstituted WMP was served in $177-\mathrm{mL}$ foam cups with lids (Dart Container Corp., Mason, MI) and straws (Solo Cup Company). Samples were prepared 1 $\mathrm{d}$ in advance and stored at $5^{\circ} \mathrm{C}$ until served.

Both milk and white chocolate bars were made by an industry partner using a fresh control WMP and each of the treatments (Table 1). Ingredients were mixed with part of the cocoa butter and refined to 25 microns, then the remainder of the cocoa butter was added and the mixture was conched for $3 \mathrm{~h}$ at $70^{\circ} \mathrm{C}$ (milk chocolate) or $55^{\circ} \mathrm{C}$ (white chocolate). The chocolate was then tempered using seed crystals formed from a small amount of the chocolate. The tempering progress was monitored using a Chocolate Temper Meter (Tricore, Elgin, IL). Once a proper temper was reached, samples were molded into bars and sealed in foil laminate packages (Printpack Inc., Elgin, IL). Chocolate was shipped to North Carolina State University and stored for $2 \mathrm{wk}$ at $20^{\circ} \mathrm{C}$ before consumer testing.
Two $25 \times 25 \mathrm{~mm}$ squares of each chocolate treatment were served in $60-\mathrm{mL}$ soufflé cups with lids. Consumers included faculty, staff, and students from North Carolina State University. Evaluations were conducted in individual sensory booths using Compusense 5 version 4.6 software (Compusense Inc.) for data collection. Room-temperature filtered water was provided for panelists to cleanse their palates between samples. Panelists were compensated with food treats and grocery store gift cards.

\section{Statistical Analysis}

The experiment was conducted as a split plot design where the whole plot was temperature and the subplot factors were atmosphere and time. The design was replicated twice in a randomized complete block design. Statistical analysis was performed using XLSTAT version 2007.5 (Addinsoft USA, New York, NY), with $P<0.05$ considered significant. Panelist was included in the model for sensory testing. The following tests were performed: ANOVA with Fisher's least significant difference for package, storage temperature, and package $\times$ storage temperature effects; Pearson correlation analysis; and principal component analysis using the correlation matrix.

\section{RESULTS AND DISCUSSION}

\section{Physicochemical Tests}

Initial Testing. The initial properties of the WMP were typical compared with previously reported US WMP values (Steen, 1977; van Mil and Jans, 1991; Liang and Hartel, 2004; USDEC, 2005; Farkye, 2006; USDA-ARS, 2007). Initial $\mathrm{a}_{\mathrm{w}}$, moisture, fat, free fat, and WPN were $0.17 \pm 0.01,2.46 \% \pm 0.06,30.05 \% \pm$ $0.45,1.61 \% \pm 0.09$, and $4.40 \mathrm{mg} / \mathrm{g} \pm 0.10$, respectively. Iron and copper content were $1.35 \pm 0.06$ and $0.19 \pm$ $0.09 \mathrm{mg} / \mathrm{kg}$, respectively. By $12 \mathrm{mo}$, both moisture and water activity increased $(P<0.05)$ to levels of $3.3 \% \pm$ 0.4 and $0.28 \pm 0.04$, respectively. The $0.8 \%$ increase in 
Table 2. Color values ${ }^{1}$ for whole milk powder stored in air or nitrogen at $2^{\circ} \mathrm{C}$ or $23^{\circ} \mathrm{C}$ for 12 mo compared with initial color values

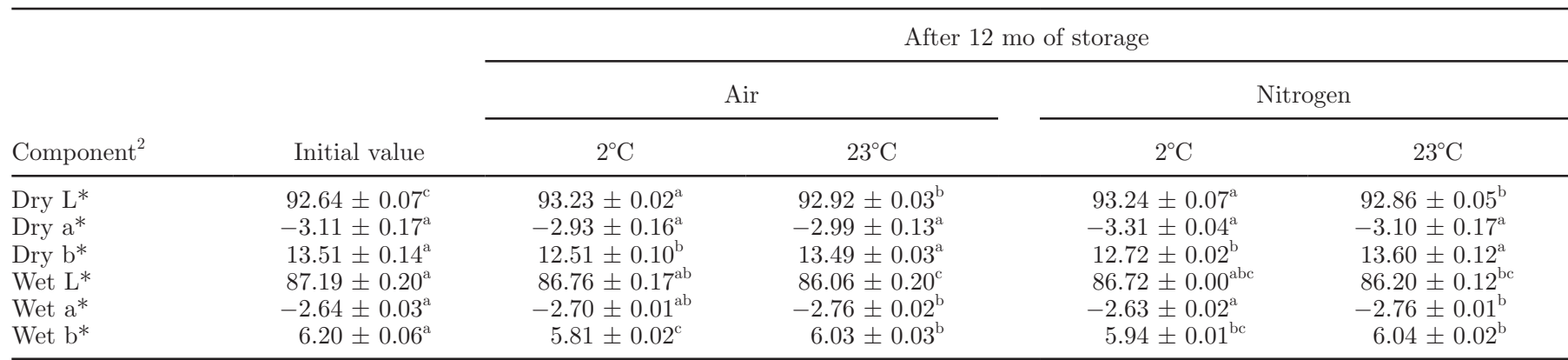

${ }^{\mathrm{a}-\mathrm{c}}$ Different superscript letters within a row indicate significant differences $(P<0.05)$.

${ }^{1}$ Data are given as means \pm SEM.

${ }^{2}$ Color values are given for the CIE L* (lightness) $a^{*}$ (redness) $b^{*}$ (yellowness) scale.

moisture we observed was reasonable, considering the $0.6 \%$ increase in moisture noted by Lim et al. (1994) in WMP that was stored in a paper/nylon/polyethylene laminate for $4 \mathrm{mo}$. Initial water activity was near the 0.2 value recommended by other researchers (Stapelfeldt et al., 1997; Schuck et al., 2007). The WPN values were within the range recommended by Baldwin et al. (1991) to improve storage stability and to prevent oxidized flavor. Both iron and copper content were well below the recommended limits of $10 \mathrm{mg} / \mathrm{kg}$ and $1.5 \mathrm{mg} / \mathrm{kg}$, respectively (ADPI, 2002).

Headspace Oxygen. Means of headspace oxygen in packaged WMP across storage were $4.0 \pm 1.1 \%$ for nitrogen-flushed WMP and $18.8 \pm 0.7 \%$ for air-packaged WMP (results not shown). No differences in headspace oxygen were observed with relation to storage time or temperature $(P>0.05)$. Van Mil and Jans (1991) reported that WMP quality was maintained for 36 mo when packaged at $6 \%$ or $<3 \%$ oxygen, with no change in trained panel flavor score and a peroxide value below $0.3 \mathrm{mEq} / \mathrm{kg}$ of fat.

Peroxide Value. Initial PV for WMP were less than $0.05 \mathrm{mEq} / \mathrm{kg}$ of fat, which fits with the recommendation of Rossell (1989) that fresh fat should have a PV $<1 \mathrm{mEq} / \mathrm{kg}$ of fat. Peroxide formation was higher in the air-packaged WMP compared with nitrogen-flushed packages (results not shown; $P<0.05$ ). There were no differences due to storage temperature $(P>0.05)$. Airpackaged treatments reached the $1 \mathrm{mEq} / \mathrm{kg}$ of fat level by 6 mo, while nitrogen-flushed treatments remained well below $1 \mathrm{mEq} / \mathrm{kg}$ of fat for the duration of the 12 -mo storage period. The air-packaged $23^{\circ} \mathrm{C}$ treatment reached $2.7 \mathrm{mEq} / \mathrm{kg}$ of fat at $10 \mathrm{mo}$, and then decreased by $12 \mathrm{mo}$. Because peroxides are primary lipid oxidation products, they typically reach a maximum level and then taper off as secondary lipid oxidation products are formed (van Mil and Jans, 1991; McCluskey et al.,
1997). Baldwin et al. (1991) measured PV from 0.03 to $3 \mathrm{mEq} / \mathrm{kg}$ of fat in New Zealand WMP stored in air for up to 18 mo. Van Mil and Jans (1991) measured PV up to $8 \mathrm{mEq} / \mathrm{kg}$ of fat in WMP stored up to $36 \mathrm{mo}$ at $20^{\circ} \mathrm{C}$.

Color. When compared with the initial value, differences in color values among the treatments were noted after 12 mo of storage (Table 2 ). Dry L* values for all treatments were lighter than the control $(P<0.05)$, with $23^{\circ} \mathrm{C}$ stored samples closer to the control than the $2^{\circ} \mathrm{C}$ samples. None of the treatments were different from the control for dry a*. For dry $\mathrm{b}^{*}$, the $2^{\circ} \mathrm{C}$ stored samples were significantly lower than the $23^{\circ} \mathrm{C}$ samples. For wet $\mathrm{L}^{*}$ and wet $\mathrm{a}^{*}$, the $2^{\circ} \mathrm{C}$ samples were not different from the control. All samples were higher than the control for wet $\mathrm{b}^{*}$ values $(P<0.05)$. Stapelfeldt et al. (1997) found increased lightness (Hunter L-value) and yellowness (Hunter b-value) during storage for dry WMP, with only small changes in Hunter L- and bvalues for WMP at low water activity, which was in agreement with our results.

Solubility Index. Solubility index was $\leq 0.1 \mathrm{~mL}$ for all treatments initially and did not change during $12 \mathrm{mo}$ of storage $(P>0.05$; data not shown). These results agree with those of Lloyd et al. (2004), who did not find any correlation between age and solubility index of SMP stored up to 29 yr. Celestino et al. (1997) noted an increase from $0.1 \mathrm{~mL}$ to $0.4 \mathrm{~mL}$ in WMP stored up to 8 mo at $25^{\circ} \mathrm{C}$; similar increases were observed by Baldwin and Ackland (1991) and van Mil and Jans (1991), who observed increases from $0.3 \mathrm{~mL}$ to $0.9 \mathrm{~mL}$ and $<0.1$ to 0.6 , respectively, for WMP stored up to $12 \mathrm{mo}$ at $30^{\circ} \mathrm{C}$. Differences in solubility index have been noted with preheat holding time before drying, season, and other factors (van Mil and Jans, 1991; Celestino et al., 1997). These values were all below the $1.0 \mathrm{~mL}$ limit set by the USDA for extra grade WMP (USDA-AMS, 2001). 


\section{Volatile Analysis}

The volatile compounds selected for quantification increased during WMP storage (Table 3; $P<0.05$ ). Initial volatile results were as expected for fresh WMP, with lipid oxidation products such as hexanal, heptanal, nonanal, and octanal at very low levels compared with stored samples (Ulberth and Roubicek, 1995; Carunchia Whetstine and Drake, 2007). Air-packaged samples were characterized by an increase in lipid oxidation volatiles during storage, while nitrogen flushing slowed the development of lipid oxidation volatiles (Figures 1 and 2). Hexanal increased most rapidly in the airpackaged, $23^{\circ} \mathrm{C}$ WMP (Figure 2). Hexanal reached a maximum at $10 \mathrm{mo}$, and then decreased by $12 \mathrm{mo}$, which could be due to breakdown of hexanal (Neilson et al., 2006; Wright et al., 2008). Storage at $23^{\circ} \mathrm{C}$ in either air or nitrogen was associated with increased levels of 2-heptanone (Table 4). Ulberth and Roubicek (1995) also noted higher levels of 2-heptanone in WMP stored at increased temperature.

Differences were noted between the initial volatile concentrations and the different treatments after 12 mo of storage (Table 4). The following volatiles were lower in the nitrogen treatments when compared with air (Figure 1 and Table 4): 2-methylbutanal, hexanal, heptanal, 1-octen-3-ol, octanal, 3-octen-2-one, and nonanal $(P<0.05)$. This is consistent with research reported by Hall et al. (1985) who found that nitrogen flushing inhibited formation of Strecker aldehydes such as 2-methylbutanal, and straight chain aldehydes such as hexanal in WMP stored at $25^{\circ} \mathrm{C}$ for 84 wk. They noted that a nitrogen storage atmosphere did not impact the formation of 2-ketones, such as 2-heptanone, which is in agreement with our results. They also observed, as we did, that dimethyl sulfide was higher in the nitrogenflushed, room-temperature WMP $(P<0.05)$. The following volatiles were higher at $23^{\circ} \mathrm{C}$ compared with $2^{\circ} \mathrm{C}$ : dimethyl sulfide, 3-methylbutanal, 2-methylbutanal, 2-heptanone, heptanal, octanal, 3-octen-2-one, and nonanal $(P<0.05)$; hexanal content was not affected by storage temperature $(P>0.05)$. These results indicate that both the storage temperature and packaging atmosphere can play a role in extending the shelf-life of WMP by inhibiting the formation of lipid oxidation volatiles. However, nitrogen flushing had a much greater effect than storage temperature in preventing the formation of hexanal, which is a key lipid oxidation product that has been associated with cardboard, grassy, and painty off-flavors (Hall and Andersson, 1985; Andersson and Lingnert, 1998; Carunchia Whetstine and Drake, 2007).

\section{Sensory Analysis}

Descriptive Analysis. Sensory changes were documented across storage temperature, time and packaging conditions (Figure 3). Initial descriptive profiles were typical of fresh WMP, including cooked, sweet aromatic and milkfat flavors and the absence of grassy or painty flavors (Hall and Lingnert, 1984; Hall and Andersson, 1985; Carunchia Whetstine and Drake, 2007); however after 3 mo of storage, air-packaged samples were characterized by grassy and painty flavors and a decrease in "fresh" flavors (Figure 4). Nitrogen-flushed WMP that were stored for $12 \mathrm{mo}$ at both temperatures did not have any detectable painty flavors, and were closer to flavor profiles of fresh WMP than air-packaged WMP after 12 mo (Figure 3 and Table 5). The $23^{\circ} \mathrm{C}$ air-packaged WMP after 12 mo was lower than all of the other treatments in milkfat and sweet aromatic flavors $(P<0.05)$, and higher in painty flavor $(P<0.05)$, indicating that it was the least well preserved. The $2^{\circ} \mathrm{C}$ air-packaged WMP also exhibited a detectable level of painty flavor. No significant differences in flavor attributes were noted between the $2{ }^{\circ} \mathrm{C}$ and $23^{\circ} \mathrm{C}$ nitrogen-flushed WMP, indicating that both treatments were similar from a sensory standpoint.

Overall, the $23^{\circ} \mathrm{C}$ stored WMP had higher intensities of cooked and milkfat flavors, while $2^{\circ} \mathrm{C}$ storage resulted in higher intensities of grassy flavor $(P<$ 0.05). Grassy flavor has been associated with hexanal (Carunchia Whetstine and Drake, 2007), but there was no difference in hexanal concentration between the WMP at the 2 storage temperatures $(P>0.05)$. Many other selected volatile components, however, were distinct between the 2 storage temperatures (Figure 1 and Table 5), which suggests that other lipid oxidation components or that a combination of these components with hexanal may contribute to grassy flavor perception. Nitrogen flushing and $2^{\circ} \mathrm{C}$ storage inhibited the development of painty flavor in WMP. Painty flavor developed in air-packaged samples between 3 and 6 mo and the intensity was lower and delayed in air-packaged WMP stored at $2^{\circ} \mathrm{C}$ compared with product that was stored at $23^{\circ} \mathrm{C}$ (results not shown). Painty flavor was absent in WMP packaged with nitrogen flushing that was stored for 12 mo (Table 5).

Relationships were observed between sensory perception and volatile compounds. Grassy flavor was correlated $(P<0.05)$ with 1 -octen-3-ol $(\mathrm{r}=0.44)$, hexanal $(\mathrm{r}=0.46)$, heptanal $(\mathrm{r}=0.48)$, and nonanal $(\mathrm{r}=$ $0.40)$ concentrations. Painty flavor was correlated $(P$ $<0.0001)$ with 2-methylbutanal $(\mathrm{r}=0.66)$, 1-octen3 -ol $(\mathrm{r}=0.88), 3$-octen-2-one $(\mathrm{r}=0.94)$, hexanal 
Table 3. Concentrations $(\mu \mathrm{g} / \mathrm{kg})$ of selected volatile compounds ${ }^{1}$ in whole milk powder during $1 \mathrm{yr}$ of storage

\begin{tabular}{|c|c|c|c|c|c|c|c|c|c|}
\hline \multirow[b]{2}{*}{ Volatile compound } & \multicolumn{8}{|c|}{ Storage time (mo) } & \multirow{2}{*}{$\begin{array}{l}\text { Regression } \\
\text { equation }^{2}\end{array}$} \\
\hline & 0 & 2 & 3 & 4 & 6 & 8 & 10 & 12 & \\
\hline Dimethyl sulfide & $25.8 \pm 6.8^{\mathrm{ab}}$ & $12.0 \pm 1.0^{c}$ & $6.4 \pm 0.5^{c}$ & $11.2 \pm 1.0^{\mathrm{c}}$ & $13.2 \pm 0.7^{\mathrm{c}}$ & $24.3 \pm 2.7^{\mathrm{b}}$ & $36.8 \pm 6.5^{\mathrm{a}}$ & $32.4 \pm 6.4^{\mathrm{ab}}$ & $\begin{aligned} \mathrm{y} & =5.09 \mathrm{x} \\
\mathrm{R}^{2} & =0.98\end{aligned}$ \\
\hline 3-Methylbutanal & $5.1 \pm 1.4^{\mathrm{bc}}$ & $3.7 \pm 0.4^{\mathrm{c}}$ & $1.8 \pm 0.2^{\mathrm{d}}$ & $3.9 \pm 0.3^{\mathrm{c}}$ & $4.5 \pm 0.4^{\mathrm{c}}$ & $7.2 \pm 0.5^{\mathrm{a}}$ & $6.5 \pm 0.7^{\mathrm{ab}}$ & $6.5 \pm 0.9^{\mathrm{ab}}$ & $\begin{aligned} \mathrm{y} & =9.35 \mathrm{x} \\
\mathrm{R}^{2} & =0.97\end{aligned}$ \\
\hline 2-Methylbutanal & $3.5 \pm 0.9^{\mathrm{bc}}$ & $2.4 \pm 0.3^{\mathrm{c}}$ & $1.9 \pm 0.2^{\mathrm{c}}$ & $3.5 \pm 0.3^{\mathrm{bc}}$ & $4.4 \pm 0.5^{\mathrm{b}}$ & $7.4 \pm 0.4^{\mathrm{a}}$ & $8.8 \pm 1.0^{\mathrm{a}}$ & $8.3 \pm 1.0^{\mathrm{a}}$ & $\begin{aligned} \mathrm{y} & =8.52 \mathrm{x} \\
\mathrm{R}^{2} & =0.98\end{aligned}$ \\
\hline Hexanal & $20.7 \pm 2.1^{c}$ & $57.9 \pm 9.1^{\mathrm{c}}$ & $118.4 \pm 37.6^{\mathrm{c}}$ & $167.2 \pm 52.2^{\mathrm{c}}$ & $421.7 \pm 120.3^{b c}$ & $605.6 \pm 139.7^{\mathrm{b}}$ & $1,174.9 \pm 259.5^{\mathrm{a}}$ & $664.7 \pm 167.9^{\mathrm{b}}$ & $\begin{aligned} \mathrm{y} & =18.67 \mathrm{x} \\
\mathrm{R}^{2} & =0.99\end{aligned}$ \\
\hline 2-Heptanone & $10.5 \pm 2.3^{\mathrm{cd}}$ & $7.2 \pm 1.0^{\mathrm{d}}$ & $6.7 \pm 0.4^{\mathrm{d}}$ & $7.6 \pm 0.8^{\mathrm{d}}$ & $9.1 \pm 1.1^{\mathrm{d}}$ & $16.3 \pm 1.9^{\mathrm{bc}}$ & $18.7 \pm 3.4^{\mathrm{b}}$ & $25.2 \pm 3.9^{\mathrm{a}}$ & $\begin{aligned} \mathrm{y} & =50.87 \mathrm{x} \\
\mathrm{R}^{2} & =1.00\end{aligned}$ \\
\hline Heptanal & $2.7 \pm 0.3^{\mathrm{d}}$ & $7.0 \pm 1.0^{\mathrm{d}}$ & $12.1 \pm 3.3^{\mathrm{d}}$ & $15.9 \pm 4.3^{\mathrm{cd}}$ & $40.0 \pm 10.5^{\mathrm{cd}}$ & $52.0 \pm 11.0^{\mathrm{bc}}$ & $113.0 \pm 23.8^{\mathrm{a}}$ & $84.7 \pm 24.0^{\mathrm{ab}}$ & $\begin{aligned} \mathrm{y} & =33.99 \mathrm{x} \\
\mathrm{R}^{2} & =0.97\end{aligned}$ \\
\hline 1-Octen-3-ol & $0.01 \pm 0.0^{c}$ & $0.4 \pm 0.0^{\mathrm{c}}$ & $0.6 \pm 0.1^{\mathrm{c}}$ & $0.5 \pm 0.1^{\mathrm{c}}$ & $1.4 \pm 0.2^{\mathrm{b}}$ & $2.2 \pm 0.2^{\mathrm{b}}$ & $4.1 \pm 0.8^{\mathrm{a}}$ & $4.0 \pm 0.9^{\mathrm{a}}$ & $\begin{aligned} \mathrm{y} & =43.02 \mathrm{x} \\
\mathrm{R}^{2} & =1.00\end{aligned}$ \\
\hline Octanal & $3.7 \pm 1.0^{\mathrm{e}}$ & $8.8 \pm 0.7^{\mathrm{de}}$ & $8.7 \pm 0.4^{\mathrm{de}}$ & $10.2 \pm 0.6^{\text {cde }}$ & $13.3 \pm 1.5^{\mathrm{cd}}$ & $16.2 \pm 1.9^{\mathrm{c}}$ & $35.9 \pm 4.4^{\mathrm{a}}$ & $28.2 \pm 5.0^{\mathrm{b}}$ & $\begin{aligned} \mathrm{y} & =66.74 \mathrm{x} \\
\mathrm{R}^{2} & =0.99\end{aligned}$ \\
\hline 3-Octen-2-one & $0.2 \pm 0.0^{\mathrm{b}}$ & $0.7 \pm 0.1^{\mathrm{b}}$ & $1.1 \pm 0.3^{\mathrm{b}}$ & $1.3 \pm 0.4^{\mathrm{b}}$ & $3.4 \pm 1.2^{\mathrm{b}}$ & $5.0 \pm 1.4^{\mathrm{b}}$ & $12.7 \pm 3.2^{\mathrm{a}}$ & $12.2 \pm 4.1^{\mathrm{a}}$ & $\begin{aligned} \mathrm{y} & =39.23 \mathrm{x} \\
\mathrm{R}^{2} & =1.00\end{aligned}$ \\
\hline Nonanal & $0.8 \pm 0.2^{\mathrm{d}}$ & $0.9 \pm 0.1^{\mathrm{d}}$ & $1.3 \pm 0.2^{\mathrm{cd}}$ & $1.3 \pm 0.2^{\mathrm{cd}}$ & $2.7 \pm 0.6^{\mathrm{cd}}$ & $3.3 \pm 0.6^{\mathrm{bc}}$ & $6.5 \pm 1.3^{\mathrm{a}}$ & $5.2 \pm 1.4^{\mathrm{ab}}$ & $\begin{aligned} \mathrm{Y} & =128.75 \mathrm{x} \\
\mathrm{R}^{2} & =1.00\end{aligned}$ \\
\hline
\end{tabular}

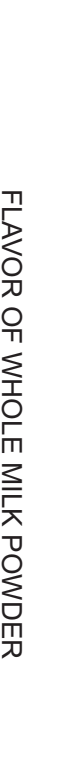




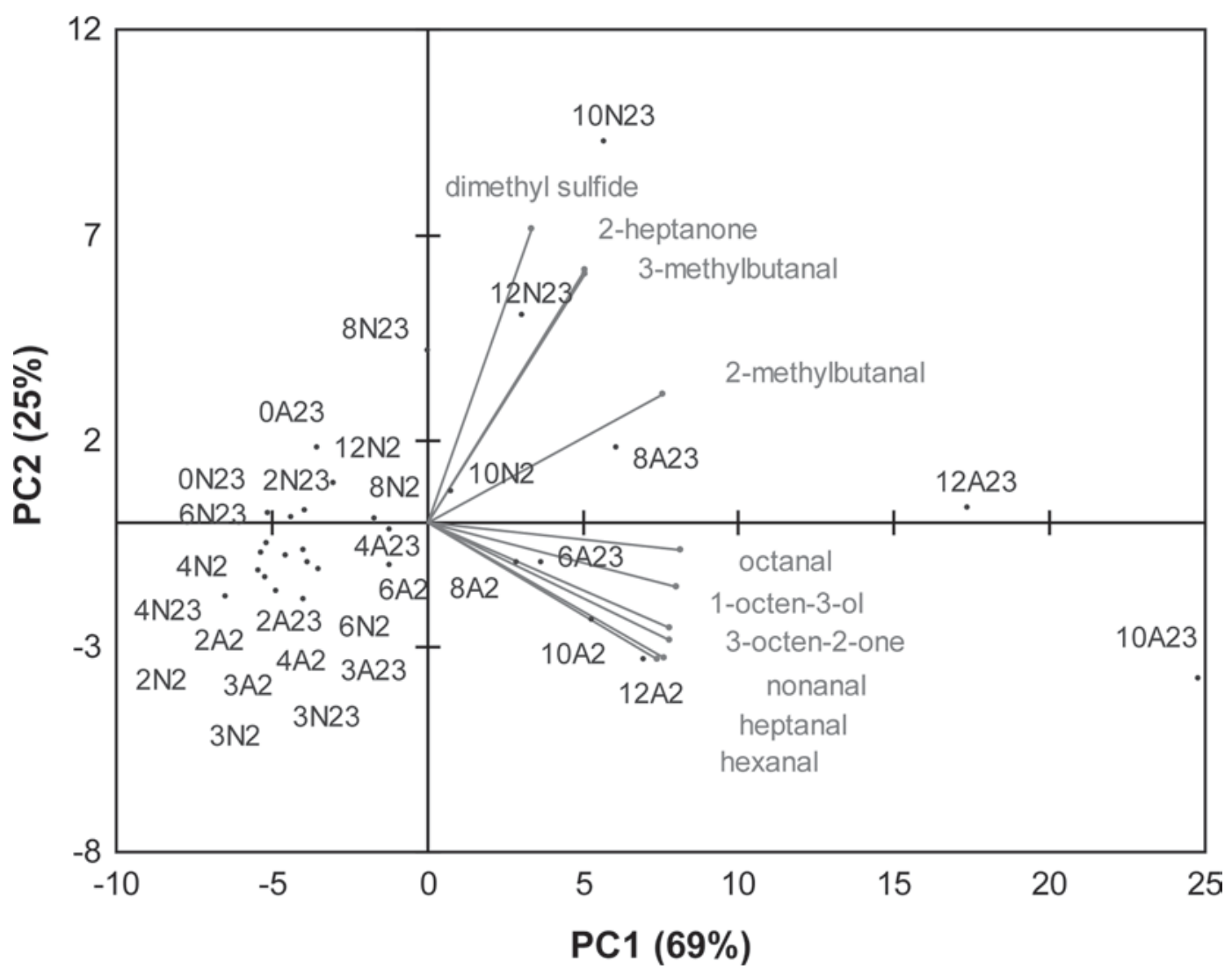

Figure 1. Principal component (PC) analysis biplot of whole milk powder volatiles. Codes represent storage time (0-12 mo), packaging (A $=$ air, $\mathrm{N}=$ nitrogen $)$, and storage temperature $\left(2^{\circ} \mathrm{C}\right.$ or $\left.23^{\circ} \mathrm{C}\right)$.

$(\mathrm{r}=0.95)$, heptanal $(\mathrm{r}=0.95)$, octanal $(\mathrm{r}=0.87)$, and nonanal $(\mathrm{r}=0.95)$ concentrations. These results are consistent with Hall and Andersson (1985), who found that changes in flavor were mostly due to lipid oxidation products, especially straight-chain aldehydes. Carunchia Whetstine and Drake (2007) reported that straight-chain aldehydes were among the odor active compounds that increased in WMP stored up to $2 \mathrm{yr}$. These researchers did not detect any grassy or painty flavors in the initial samples by descriptive analysis, but these flavors developed during storage.

Peroxide value was correlated $(P<0.0001)$ with hexanal $(\mathrm{r}=0.91)$ and painty flavor $(\mathrm{r}=0.86)$. Baldwin et al. (1991) reported a correlation of 0.73 between $\mathrm{PV}$ and trained panel perception of oxidized flavor. Van Mil and Jans (1991) reported that trained judges could detect oxidized off-flavors in WMP when PV reached $2 \mathrm{mEq} / \mathrm{kg}$ of fat, which occurred around $2 \mathrm{yr}$ for their WMP. Our research showed distinct flavor changes before the PV reached $1 \mathrm{mEq} / \mathrm{kg}$ of fat, which could be due to use of a different PV method, or a more sensitive trained panel.

\section{Consumer Acceptance}

Fluid whole milk scored higher $(P<0.05)$ than the WMP control (6.6 versus 6.1) for overall acceptance. When compared with the fresh control WMP, consumer acceptance of reconstituted WMP dropped after 3 mo of storage for all treatments $(P<0.05$; Figure 4$)$. This was likely due to decreases in "fresh" flavors (cooked/ sulfurous, sweet aromatic, and milkfat flavor intensities) and the development of grassy and painty flavors in the WMP, which were more prevalent in the airpackaged WMP. Nitrogen-flushed WMP scored higher in overall acceptance than air treatments over 12 mo of storage, consistent with trained panel profiles and lipid oxidation compounds $(P<0.05)$. Storage temperature of WMP did not influence consumer acceptance $(P>$ $0.05)$.

Consumer acceptance was positively correlated $(P$ $<0.05)$ with trained panel attributes associated with freshly produced WMP, including cooked/sulfurous, milkfat, and sweet taste $(\mathrm{r}=0.76,0.91$, and 0.83 , respectively); acceptance was negatively correlated 
Table 4. Mean concentrations $(\mu \mathrm{g} / \mathrm{kg})$ of selected volatile compounds in whole milk powder stored in air or nitrogen at $2^{\circ} \mathrm{C}$ or $23^{\circ} \mathrm{C}$ for 12 mo compared with initial values ${ }^{1}$

\begin{tabular}{|c|c|c|c|c|c|}
\hline Volatile compound & Initial value & \multicolumn{4}{|c|}{ After $12 \mathrm{mo}$ of storage } \\
\hline Dimethyl sulfide & $25.8 \pm 6.8^{\mathrm{b}}$ & $16.4 \pm 5.6^{\mathrm{b}}$ & $26.5 \pm 9.0^{\mathrm{ab}}$ & $32.6 \pm 3.8^{\mathrm{ab}}$ & $54.3 \pm 17.5^{\mathrm{a}}$ \\
\hline 3-Methylbutanal & $5.1+1.4^{\mathrm{a}}$ & $4.0+0.8^{\mathrm{a}}$ & $8.6+2.2^{\mathrm{a}}$ & $3.9+0.3^{\mathrm{a}}$ & $8.0+1.3^{\mathrm{a}}$ \\
\hline 2-Methylbutanal & $3.5 \pm 0.9^{c}$ & $4.5 \pm 0.9^{\mathrm{c}}$ & $12.9 \pm 1.7^{\mathrm{a}}$ & $4.9 \pm 0.6^{\mathrm{bc}}$ & $9.2 \pm 1.4^{\mathrm{b}}$ \\
\hline Heptanal & $2.7 \pm 0.3^{\mathrm{b}}$ & $133.1 \pm 49.0^{\mathrm{a}}$ & $144.5 \pm 53.7^{\mathrm{a}}$ & $8.0 \pm 0.7^{\mathrm{b}}$ & $14.9 \pm 4.6^{\mathrm{b}}$ \\
\hline 1-Octen-3-ol & $0.01 \pm 0.0^{\mathrm{c}}$ & $4.1 \pm 1.6^{\mathrm{ab}}$ & $7.1 \pm 2.1^{\mathrm{a}}$ & $0.3 \pm 0.3^{\mathrm{bc}}$ & $2.8 \pm 0.3^{\mathrm{bc}}$ \\
\hline Octanal & $3.7 \pm 1.0^{\mathrm{c}}$ & $29.0 \pm 6.7^{\mathrm{ab}}$ & $47.0 \pm 13.2^{\mathrm{a}}$ & $12.5 \pm 1.2^{\mathrm{bc}}$ & $16.4 \pm 1.4^{\mathrm{bc}}$ \\
\hline 3 -Octen-2-one & $0.2 \pm 0.0^{\mathrm{c}}$ & $13.4 \pm 5.2^{\mathrm{ab}}$ & $27.7 \pm 10.9^{\mathrm{a}}$ & $0.2 \pm 0.2^{\mathrm{bc}}$ & $1.5 \pm 0.5^{\mathrm{bc}}$ \\
\hline Nonanal & $0.8 \pm 0.2^{\mathrm{b}}$ & $7.7 \pm 2.7^{\mathrm{a}}$ & $8.9 \pm 3.0^{\mathrm{a}}$ & $0.7 \pm 0.1^{\mathrm{b}}$ & $1.2 \pm 0.2^{\mathrm{b}}$ \\
\hline
\end{tabular}

${ }^{\mathrm{a}-\mathrm{c}}$ Different superscript letters within a row indicate significant differences $(P<0.05)$.

${ }^{1}$ Data are given as means \pm SEM.

$(P<0.05)$ with astringency, painty, and grassy flavors $(-0.68,-0.77$, and -0.84 , respectively), as well as the following lipid oxidation products: 1-octen-3-ol, 3-octen-2-one, heptanal, hexanal, nonanal, and octanal $(\mathrm{r}=-0.59$ to -0.67$)$. Similarly, Hough et al. (2002) reported that increased levels of oxidized flavor, as determined by a trained panel, resulted in decreased consumer acceptance. Caudle et al. (2005) also reported that SMP with off-flavors received decreased consumer acceptance scores when compared with freshly manufactured SMP that was free of off-flavors.

Differences in WMP treatments were more subtle when incorporated into chocolate, probably because of flavor masking by the other ingredients. Chocolates at

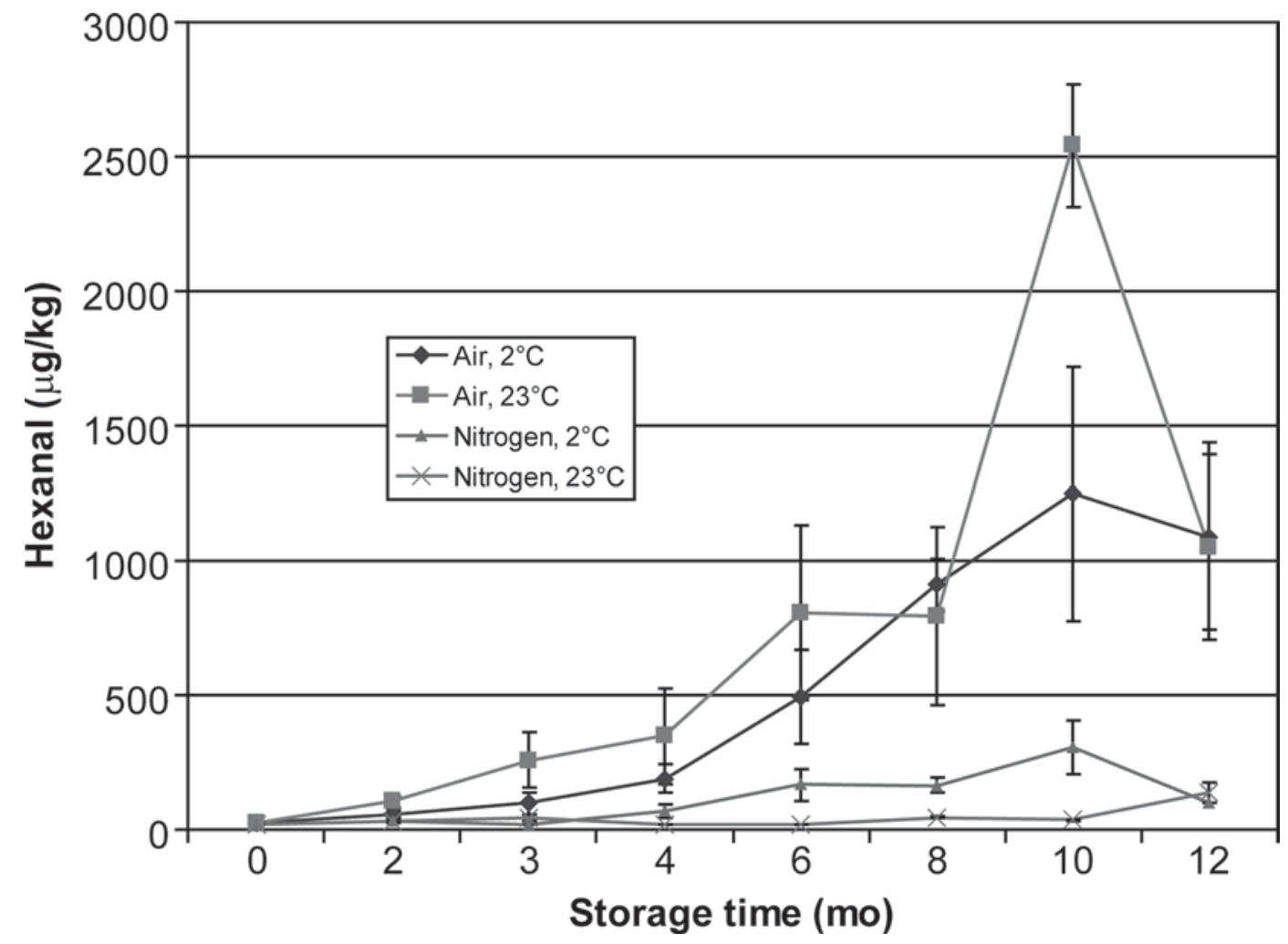

Figure 2. Development of hexanal in whole milk powder stored in air or nitrogen at $2^{\circ} \mathrm{C}$ or $23^{\circ} \mathrm{C}$. Each point represents the mean from triplicate measurements. Bars represent standard errors of the means. 


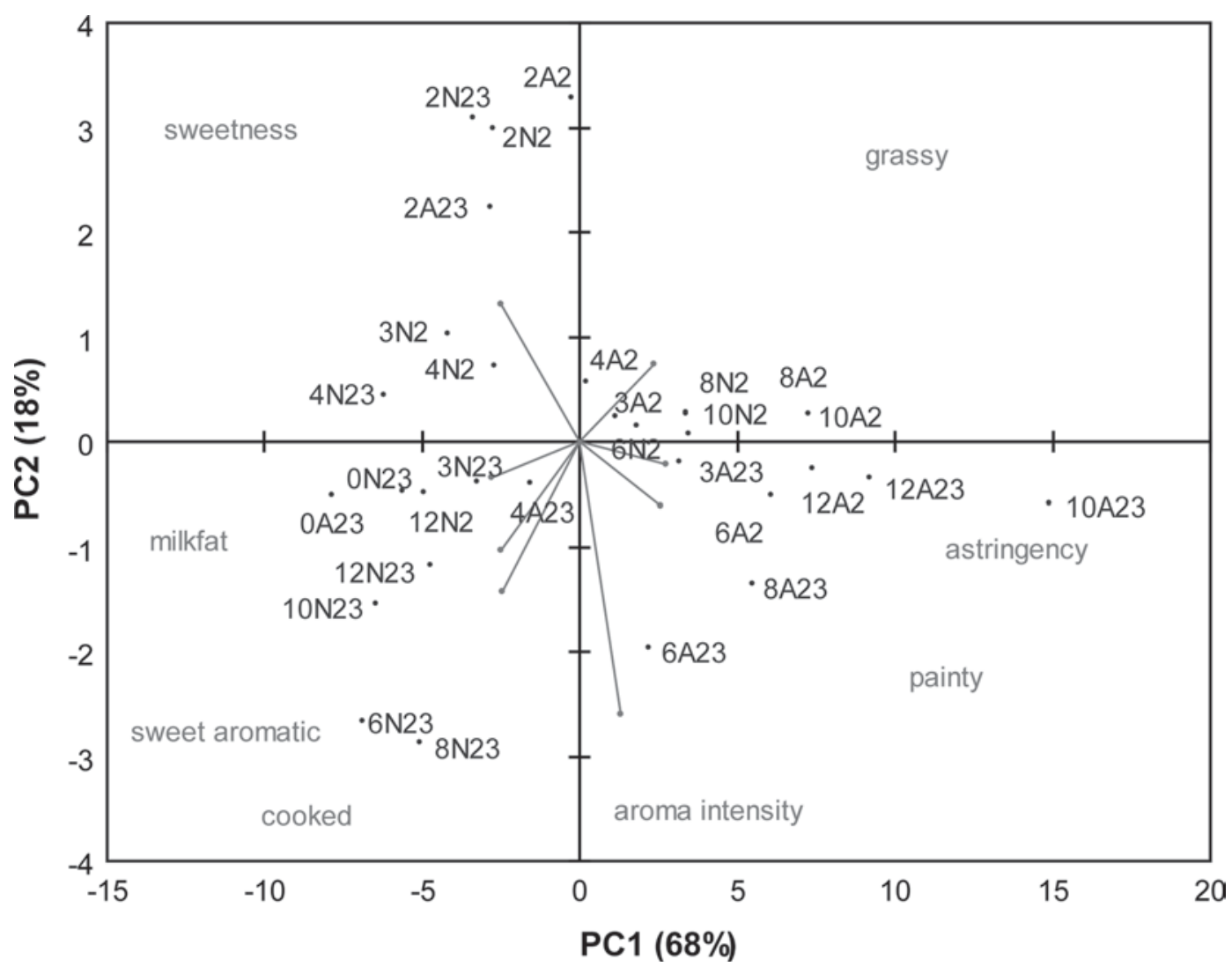

Figure 3. Principal component (PC) analysis biplot of whole milk powder descriptive sensory analysis. Codes represent storage time (0-12 mo), packaging $(\mathrm{A}=$ air, $\mathrm{N}=$ nitrogen $)$, and storage temperature $\left(2^{\circ} \mathrm{C}\right.$ or $\left.23^{\circ} \mathrm{C}\right)$.

all time points scored greater than 5 on the 9-point hedonic scale, indicating that they were all generally liked. Air-packaged $23^{\circ} \mathrm{C}$ treatments were less acceptable than other treatments after 3 mo for white chocolate (Figure 5 ), and after 6 mo for milk chocolate (Figure 6). Dif- ferences noted between white and milk chocolate were also likely caused by differing degrees of flavor masking among these 2 products. Both Caudle et al. (2005) and Childs et al. (2007) noted differences in flavor carrythrough (measured by consumer acceptance testing) of

Table 5. Mean intensities of flavor attributes ${ }^{1}$ in whole milk powder stored in air or nitrogen at $2^{\circ} \mathrm{C}$ or $23^{\circ} \mathrm{C}$ for 12 mo compared with initial values

\begin{tabular}{|c|c|c|c|c|c|}
\hline \multirow[b]{3}{*}{ Flavor attribute } & \multirow[b]{3}{*}{ Initial value } & \multicolumn{4}{|c|}{ After 12 mo of storage } \\
\hline & & \multicolumn{2}{|c|}{ Air } & \multicolumn{2}{|c|}{ Nitrogen } \\
\hline & & $2^{\circ} \mathrm{C}$ & $23^{\circ} \mathrm{C}$ & $2^{\circ} \mathrm{C}$ & $23^{\circ} \mathrm{C}$ \\
\hline Aroma intensity & $2.0^{\mathrm{b}}$ & $2.1^{\mathrm{a}}$ & $2.1^{\mathrm{a}}$ & $2.0^{\mathrm{ab}}$ & $2.1^{\mathrm{a}}$ \\
\hline Cooked/sulfurous & $2.6^{\mathrm{a}}$ & $2.0^{\mathrm{c}}$ & $1.9^{\mathrm{c}}$ & $2.3^{\mathrm{b}}$ & $2.3^{\mathrm{b}}$ \\
\hline Milkfat & $2.7^{\mathrm{a}}$ & $2.0^{\mathrm{c}}$ & $1.8^{\mathrm{d}}$ & $2.4^{\mathrm{b}}$ & $2.5^{\mathrm{b}}$ \\
\hline Sweet aromatic/caramelized & $2.6^{\mathrm{a}}$ & $1.9^{\mathrm{c}}$ & $1.7^{\mathrm{d}}$ & $2.3^{\mathrm{ab}}$ & $2.4^{\mathrm{a}}$ \\
\hline Grassy & $\mathrm{ND}^{2}$ & $2.1^{\mathrm{a}}$ & $1.7^{\mathrm{a}}$ & $0.6^{\mathrm{b}}$ & $0.7^{\mathrm{b}}$ \\
\hline Painty/fatty & ND & $1.0^{\mathrm{b}}$ & $1.6^{\mathrm{a}}$ & ND & ND \\
\hline Sweet taste & $2.2^{\mathrm{a}}$ & $1.8^{\mathrm{b}}$ & $1.8^{\mathrm{b}}$ & $2.1^{\mathrm{a}}$ & $2.1^{\mathrm{a}}$ \\
\hline Astringency & $1.1^{\mathrm{b}}$ & $1.2^{\mathrm{a}}$ & $1.3^{\mathrm{a}}$ & $1.0^{\mathrm{b}}$ & $1.0^{\mathrm{b}} \quad \mathrm{c}^{2} \mathrm{c}$ \\
\hline
\end{tabular}

${ }^{\mathrm{a}-\mathrm{d}}$ Different superscript letters within a row indicate significant differences $(P<0.05)$.

${ }^{1}$ Attributes were scored on a 0 to 15 point universal Spectrum intensity scale where $0=$ absence of the attribute and $15=$ extremely high intensity of the attribute (Meilgaard et al., 1999). Most reconstituted dried dairy ingredient flavors fall between 0 and 4 on this scale (Drake et al., 2003; Drake, 2004; Carunchia Whetstine and Drake, 2007; Wright et al., 2008).

${ }^{2} \mathrm{ND}=$ not detected 
dried ingredients in different ingredient applications. Nitrogen-flushed WMP stored up to 1 yr at both temperatures produced both white and milk chocolate that was not different from the fresh control $(P>0.05)$. Unlike consumer acceptance of reconstituted WMP, acceptance of both white and milk chocolate was not correlated $(P>0.05)$ with grassy flavor in WMP (r $=-0.26$ and -0.02 , respectively), indicating that this off-flavor was well-masked by the other ingredients. Consumer acceptance of both white and milk chocolate was negatively correlated with painty flavor and lipid oxidation volatiles $(P<0.05, \mathrm{r}=-0.54$ to -0.84$)$. Correlation values were generally higher for white chocolate than for milk chocolate and this difference may reflect that white chocolate is a more delicately flavored application than milk chocolate and is thus more susceptible to flavor carry-through from ingredients.

Whole milk powder stored at $2^{\circ} \mathrm{C}$ produced white and milk chocolate with higher acceptance than WMP stored at $23^{\circ} \mathrm{C}$ after 3 or 6 mo of storage, respectively (Figures 5 and 6). Also, milk chocolate acceptance was negatively correlated with the presence of 2-methylbutanal and 3-methylbutanal in the WMP $(P<0.05$, $\mathrm{r}=-0.57$ and -0.58 , respectively), which are associ- ated with malty flavor (Avsar et al., 2004; Carunchia Whetstine and Drake, 2007). Bolenz et al. (2003) found that consumer acceptance was negatively affected by the presence of malty $(\mathrm{r}=-0.789)$ flavor in chocolate contributed by dry dairy ingredients. As mentioned previously, these compounds were found at higher levels in WMP stored at $23^{\circ} \mathrm{C}$, regardless of storage atmosphere. This result suggests that a cooler storage temperature of $2^{\circ} \mathrm{C}$, in combination with nitrogen flushing, would be beneficial to shelf-life extension of WMP, especially if it is to be used in chocolate.

\section{CONCLUSIONS}

Optimum shelf-life of WMP from a flavor standpoint was about 3 mo. By 3 mo, WMP exhibited a loss of "fresh" flavors and/or developed a grassy off-flavor, which significantly decreased consumer acceptance of reconstituted WMP, regardless of package atmosphere or storage temperature. After 6 mo, painty off-flavors in WMP were detected by consumers in chocolate. Nitrogen flushing greatly enhanced storage stability of WMP by preventing the development of painty flavor. Packaging headspace oxygen levels should be as low

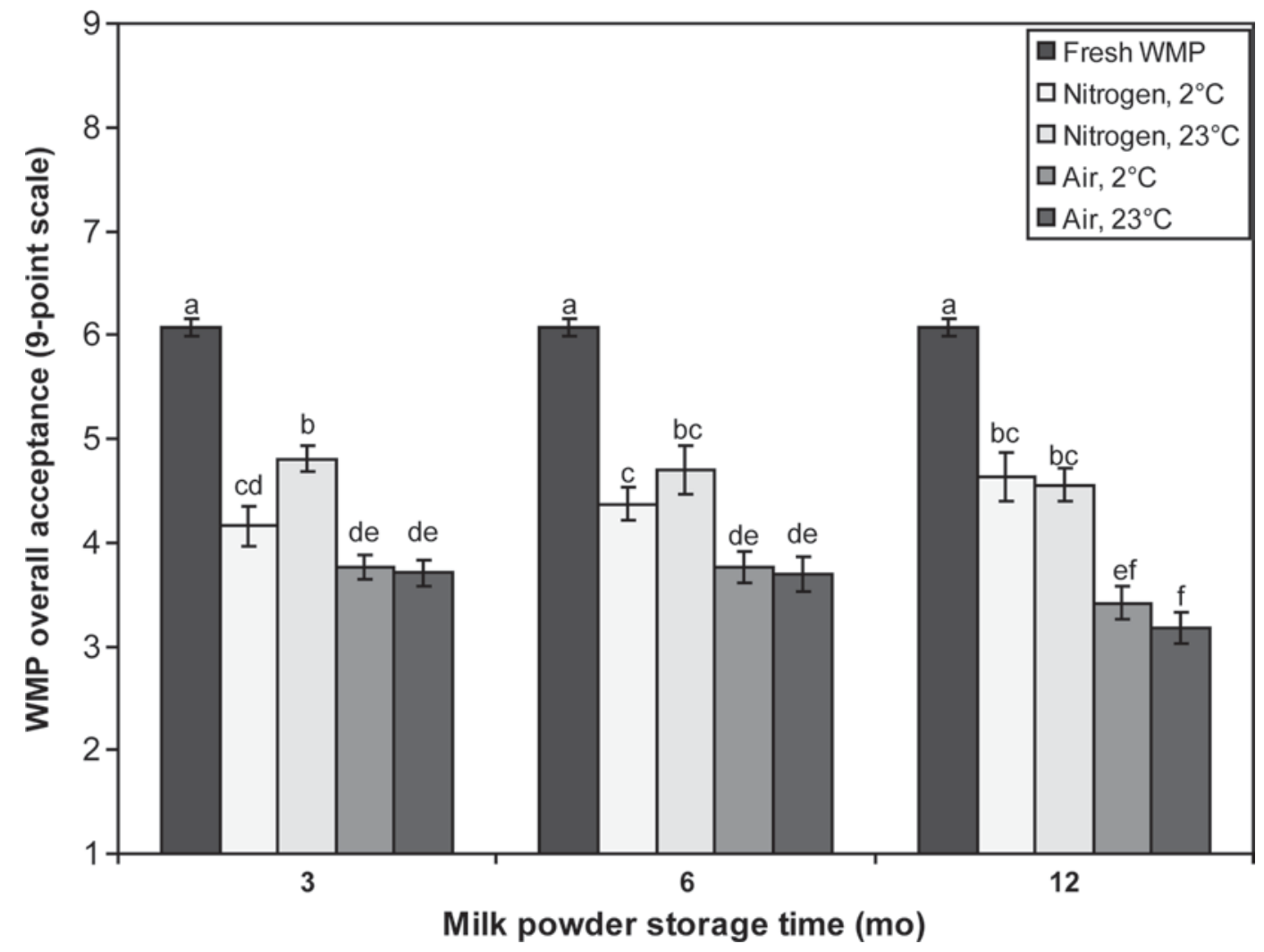

Figure 4. Consumer acceptance of reconstituted whole milk powder (WMP) stored up to 1 y in air or nitrogen at $2^{\circ} \mathrm{C}$ or $23^{\circ} \mathrm{C}$, evaluated every 3 mo. Acceptance was scored on a 9 -point hedonic scale where $1=$ dislike extremely and $9=$ like extremely. ${ }^{\mathrm{a} e \mathrm{e}}$ Different letters indicate significant differences $(P<0.05)$. 


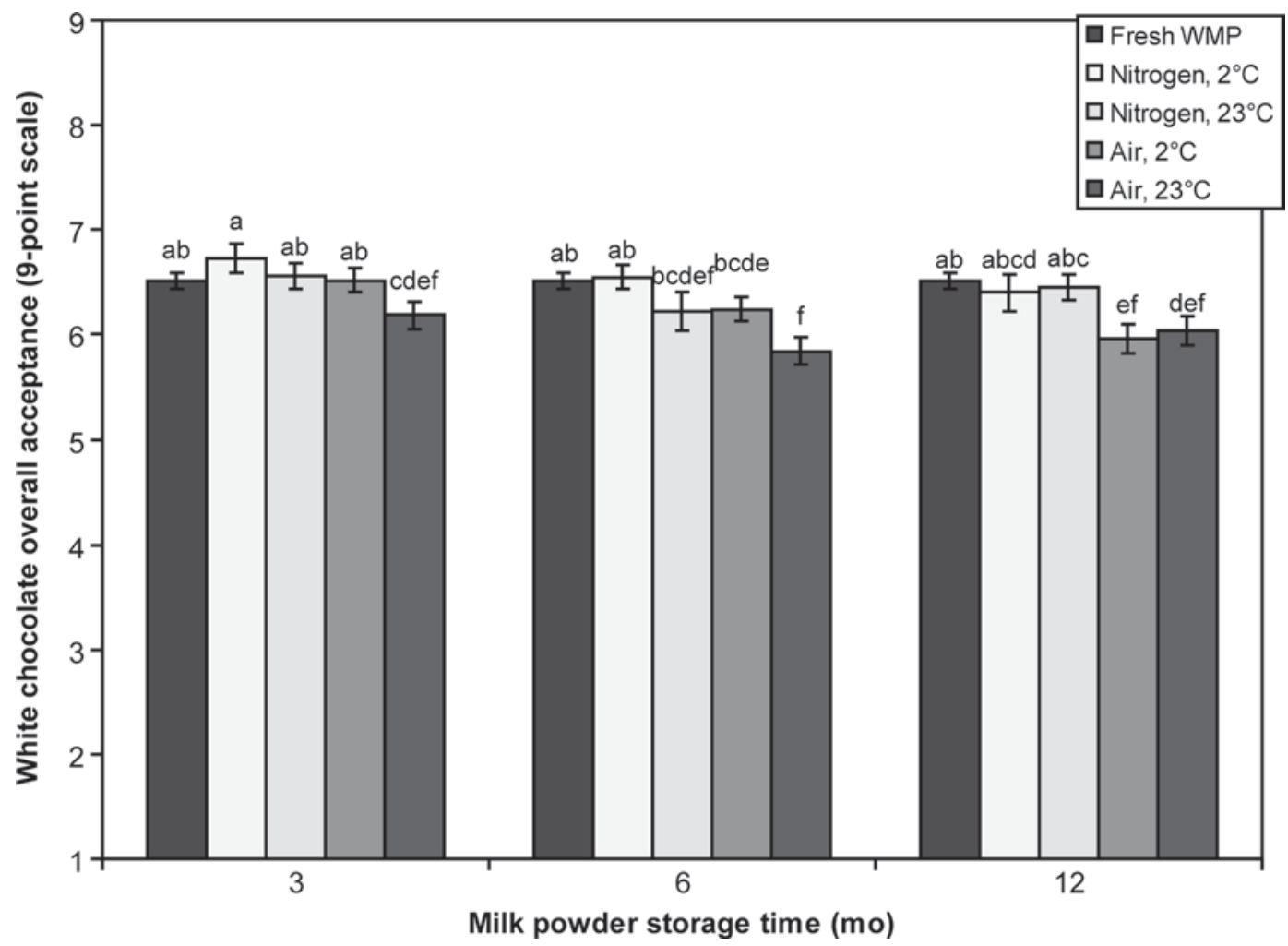

Figure 5. Consumer acceptance of white chocolate made from whole milk powder (WMP) stored up to a year in air or nitrogen at $2^{\circ} \mathrm{C}$ or $23^{\circ} \mathrm{C}$, evaluated every 3 mo. Acceptance was scored on a 9 -point hedonic scale where $1=$ dislike extremely and $9=$ like extremely. ${ }^{\text {a-f }}$ Different letters indicate significant differences $(P<0.05)$.

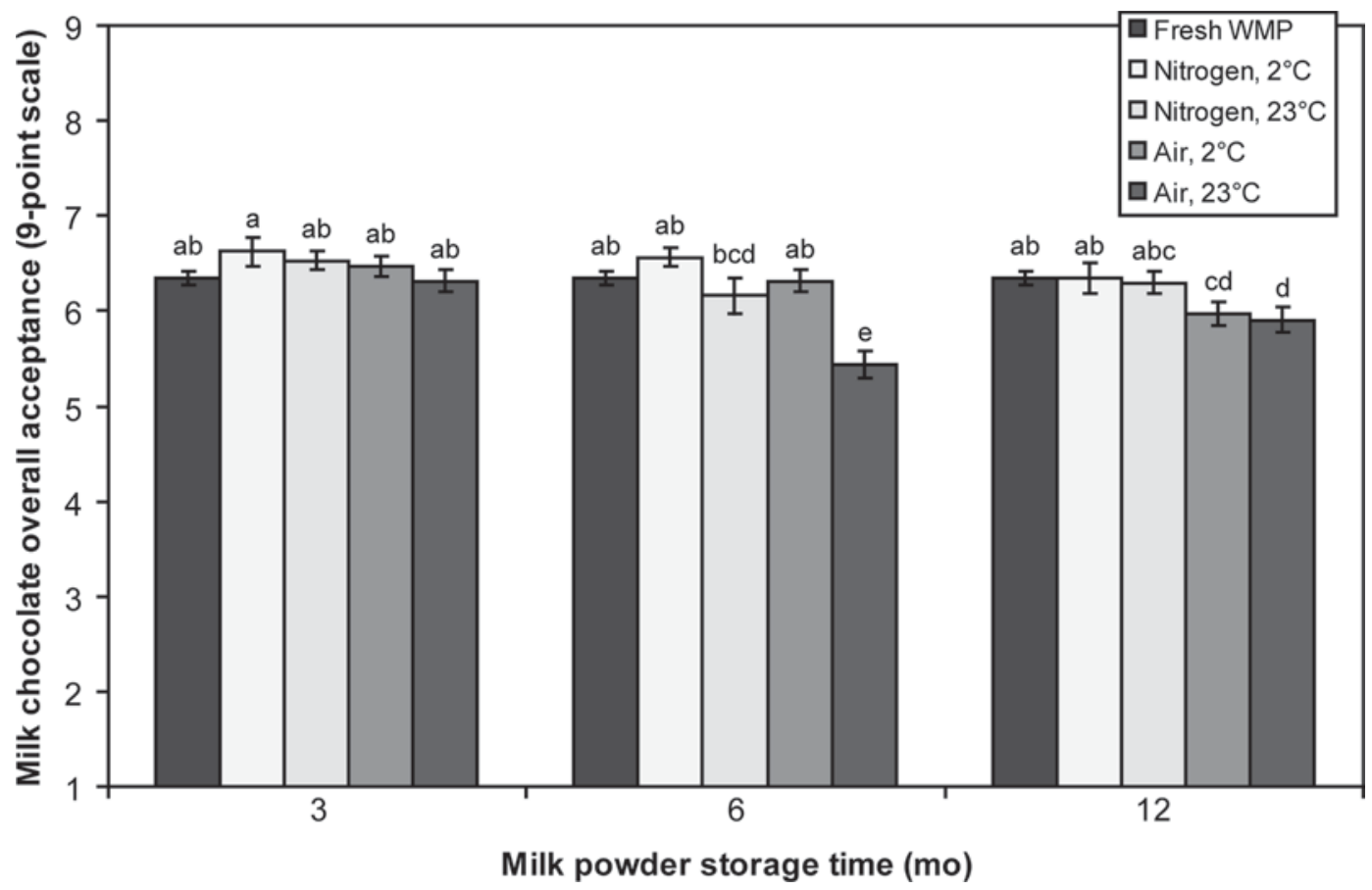

Figure 6. Consumer acceptance of milk chocolate made from whole milk powder (WMP) stored up to a year in air or nitrogen at $2^{\circ} \mathrm{C}$ or $23^{\circ} \mathrm{C}$, evaluated every 3 mo. Acceptance was scored on a 9 -point hedonic scale where $1=$ dislike extremely and $9=$ like extremely. ${ }^{\text {ae }}$ Different letters indicate significant differences $(P<0.05)$. 
as possible to prevent lipid oxidation and off-flavors. Cooler storage temperatures also enhanced storage stability of WMP, but to a lesser extent than nitrogen flushing. Whole milk powder stored in nitrogen-flushed packaging for up to a year could be used to manufacture milk chocolate with a high level of consumer acceptance. However, the shelf life of chocolate made from fresh or stored WMP has not been compared. Further research should track changes in consumer acceptance and flavor changes in chocolate bars for up to a year after production (standard shelf life).

\section{ACKNOWLEDGMENTS}

Funding was provided by the California Dairy Research Foundation (Davis, CA) and the Hershey Company (Hershey, PA). The assistance of Mike Zanos and Foster Farms Dairy (Modesto, CA) and Ron Thompson and California Dairies, Inc. (Visalia, CA) are gratefully acknowledged. Paper number FSR 09-02 of the journal article series of the Department of Food, Bioprocessing, and Nutritional Sciences, North Carolina State University. The use of trade names does not imply endorsement nor lack of endorsement for those not mentioned.

\section{REFERENCES}

ADPI. 2002. Standards for grades of dry milks, including methods of analysis (Bulletin 916). American Dairy Products Institute, Elmhurst, IL.

Andersson, K., and H. Lingnert. 1998. Influence of oxygen concentration on the flavour and chemical stability of cream powder. Lebenson. Wiss. Technol. 31:245-251.

Avsar, Y. K., Y. Karagul-Yuceer, M. A. Drake, T. K. Singh, Y. Yoon, and K. R. Cadwallader. 2004. Characterization of nutty flavor in Cheddar cheese. J. Dairy Sci. 87:1999-2010.

Baldwin, A. J., and J. D. Ackland. 1991. Effect of preheat treatment and storage on the properties of whole milk powder - Changes in physical and chemical properties. Neth. Milk Dairy J. 45:169181.

Baldwin, A. J., H. R. Cooper, and K. C. Palmer. 1991. Effect of preheat treatment and storage on the properties of whole milk powderChanges in sensory properties. Neth. Milk Dairy J. 45:97-116.

Bolenz, S., T. Thiessenhusen, and R. Schape. 2003. Influence of milk components on properties and consumer acceptance of milk chocolate. Eur. Food Res. Technol. 216:28-33.

Carunchia Whetstine, M. E., and M. A. Drake. 2007. The flavor and flavor stability of skim and whole milk powders. Pages 217-251 in Flavor of Dairy Products. K. R. Cadwallader, M. A. Drake, R. McGorrin, ed. ACS Publishing, Washington, DC.

Caudle, A. D., Y. Yoon, and M. A. Drake. 2005. Influence of flavor variability in skim milk powder on consumer acceptability of ingredient applications. J. Food Sci. 70:S427-S431.

Celestino, E. L., M. Iyer, and H. Roginski. 1997. The effects of refrigerated storage of raw milk on the quality of whole milk powder stored for different periods. Int. Dairy J. 7:119-127.

Childs, J. L., M. D. Yates, and M. A. Drake. 2007. Sensory properties of meal replacement bars and beverages made from whey or soy proteins. J. Food Sci. 72:S425-S434.

Drake, M. A. 2004. ADSA Foundation Scholar Award: Defining dairy flavors. J. Dairy Sci. 87:777-784.
Drake, M. A., Y. Karagul-Yuceer, K. R. Cadwallader, G. V. Civille, and P. S. Tong. 2003. Determination of the sensory attributes of dried milk powders and dairy ingredients. J. Sens. Stud. 18:199216.

Farkye, N. 2006. Significance of milk fat in milk powder. Pages 451465 in Advanced Dairy Chemistry, Vol 2. Lipids, 3rd ed. P. Fox and P. McSweeney, ed. Springer US, New York, NY.

Hall, G., and J. Andersson. 1985. Flavor changes in whole milk powder during storage. 3. Relationships between flavor properties and volatile compounds. J. Food Qual. 7:237-253.

Hall, G., J. Andersson, H. Lingnert, and B. Olofsson. 1985. Flavor changes in whole milk powder during storage. 2. The kinetics of the formation of volatile fat oxidation-products and other volatile compounds. J. Food Qual. 7:153-190.

Hall, G., and H. Lingnert. 1984. Flavor changes in whole milk powder during storage. 1. Odor and flavor profiles of dry milk with additions of antioxidants and stored under air or nitrogen. J. Food Qual. 7:131-151.

Hough, G., R. H. Sanchez, G. G. de Pablo, R. G. Sanchez, S. C. Villaplana, A. M. Gimenez, and A. Gambaro. 2002. Consumer acceptability versus trained sensory panel scores of powdered milk shelf-life defects. J. Dairy Sci. 85:2075-2080.

IDF. 1997. Standard 99C: Sensory evaluation of dairy products by scoring reference methodology. International Dairy Federation, Brussels, Belgium.

Lentz, L. 2008. Personal Communication. Analytical Services Lab. North Carolina State University.

Liang, B., and R. W. Hartel. 2004. Effects of milk powders in milk chocolate. J. Dairy Sci. 87:20-31.

Lim, S. D., K. S. Kim, D. J. Park, T. S. Kang, and N. H. Lee. 1994. Effects of packaging conditions on the quality of whole milk powder. (1). Changes in physico-chemical properties during storage. Korean J. Anim. Sci. 36:90-99.

Lloyd, M. A., J. Zou, L. V. Ogden, and O. A. Pike. 2004. Sensory and nutritional quality of nonfat dry milk in long-term residential storage. J. Food Sci. 69:S326-S331.

MacFie, H., K. Greenhoff, and I. Vallis. 1989. Designs to balance the effect of order of presentation and first-order carry-over effects in hall tests. J. Sens. Stud. 4:129-148.

McCluskey, S., J. F. Connolly, R. Devery, B. O'Brien, J. Kelly, D. Harrington, and C. Stanton. 1997. Lipid and cholesterol oxidation in whole milk powder during processing and storage. J. Food Sci. 62:331-337.

Meilgaard, M. M., G. V. Civille, and T. Carr. 1999. Sensory Evaluation Techniques. 3rd ed. CRC Press, New York, NY.

Neilson, A. P., H. F. Pahulu, L. V. Ogden, and O. A. Pike. 2006. Sensory and nutritional quality of dehydrated potato flakes in long-term storage. J. Food Sci. 71:S461-S466.

Nielsen, B. R., H. Stapelfeldt, and H. Skibsted. 1997. Early prediction of the shelf-life of medium-heat whole milk powders using stepwise multiple regression and principal component analysis. Int. Dairy J. $7: 341-348$.

Nursten, H. E. 1997. The flavour of milk and dairy products.1. Milk of different kinds, milk powder, butter and cream. Int. J. Dairy Technol. 50:48-56.

Rossell, J. 1989. Measurement of rancidity. Pages $22-51$ in Rancidity in Foods. J. Allen and R. Hamilton, ed. Elsevier Appl. Sci., London, UK.

Schuck, P., S. Mejean, A. Dolivet, R. Jeantet, and B. Bhandari. 2007. Keeping quality of dairy ingredients. Lait 87:481-488.

Sørensen, I. H., J. Krag, J. Pisecky, and V. Westergaard. 1978. Analytical Methods for Dry Milk Products, 4th ed. NIRO A/S, Copenhagen, Denmark. Available from: http://www.niro.dk/niro/ cmsdoc.nsf/WebDoc/ndkw6dknxs. Accessed Aug 18, 2008.

Stapelfeldt, H., B. R. Nielsen, and L. H. Skibsted. 1997. Effect of heat treatment, water activity and storage temperature on the oxidative stability of whole milk powder. Int. Dairy J. 7:331-339.

Steen, K. 1977. Seasonal variations in the composition of dry whole milk and its keeping qualities under storing. Maelkeritidende 90(5-6):126-140, 152-68. 
Tuohy, J. 1984. Developments in the packaging of whole milk powder. Farm Food Res. 15:7-9.

Ulberth, F., and D. Roubicek. 1995. Monitoring of oxidative deterioration of milk powder by headspace gas-chromatography. Int. Dairy J. 5:523-531.

United States Dairy Export Council. 2005. Reference Manual for US Milk Powders: 2005 Revised Edition. Available from: http:/ www.usdec.org/publications/PubDetail.cfm?ItemNumber $=213$ Accessed July 22, 2008.

United States Department of Agriculture-Agricultural Marketing Service. 2001. DA Instruction No. 918-RL. Available from: Dairy Grading Branch, Dairy Division. USDA-AMS, Washington, DC.

United States Department of Agriculture-Agricultural Research Service. 2007. USDA National Nutrient Database for Standard Reference, Release 20. Available from: http://www.ars.usda.gov/ main/site_main.htm? modecode $=12354500$. Accessed Aug 18, 2008 . van Den Dool, H., and P. D. Kratz. 1963. A generalization of retention index system including linear temperature programmed gas-liquid partition chromatography. J. Chromatogr. A 11:463-471.

Van Mil, P., and J. A. Jans. 1991. Storage stability of whole milk powder: Effects of process and storage conditions on product properties. Neth. Milk Dairy J. 45:145-167.

Vazquez-Landaverde, P. A., G. Velazquez, J. A. Torres, and M. C Qian. 2005. Quantitative determination of thermally derived offflavor compounds in milk using solid-phase microextraction and gas chromatography. J. Dairy Sci. 88:3764-3772.

Wehr, H., and J. Frank. 2004. Standard Methods for the Examination of Dairy Products. 17th ed. American Public Health Association, Washington, DC.

Wright, B. J., S. E. Zevchak, J. M. Wright, and M. A. Drake. 2008. Impact of agglomeration on flavor and flavor stability of whey proteins. J. Food Sci. (in press). 